\title{
Character Education Insightful Nationality: A Multi Cultural Approach
}

\section{Chairul Anwar}

The State Islamic Institute of Raden Intan, Endro Suratmin Streat No 1, Sukarame Bandar Lampung Indonesia

\section{Doi:10.5901/mjss.2016.v7n2s1p182}

\section{Abstract}

The problems faced by Indonesia as a nation with a population of 250 million people, where $90 \%$ of the population is Muslim, 250 ethnic groups, 250 more local languages, 17,000 islands, and more than 6 official religions and faiths, is a historical fact inevitable. This fact is a blessing and a challenge. Blessing if the plurality that can be managed with wisdom and tact, but the biggest challenge when a plurality is not able to run well. Conflicts small but quite often the case for this is the harsh reality that demands solution and a way out wise. Education is one of the foundation hopes to take part in the multi-cultural management, especially the character-based education and nationality insight that had been considered in deficit since the fall of the New Order. Through multi-cultural approach, national awareness deficit can be overcome through education to reintroduce nonstop national spirit pluralist and multi-cultural.

Keywords: Character Education, a Multi-Cultural Approach

\section{Introduction}

Many observers of education in Indonesia were startled when reading books on Islamic Education and Character Education class XI official publication of the Ministry of Education and Culture, which contained the phrase "The killing of those who or ship other than Allah latters should be done". This sentence is obviously directed at religious radicalism is contrary to the constitution which emphasizes the principle of appreciation of the various religions, beliefs, cultures and classes. The statement in the book implies the existence of a strong suspicion about the process of infiltration of radical understood in the formula. Understand the process of infiltration of radical today is a lot going on in various institutions and text books in Indonesia as part of their Islamic business class line exert influence.

Especially if it is associated with the findings Muhammad Wahyuni Nafis (2001) on religious instruction in formal educational institutions we are still more leads to the missionary spirit and missionary who assert truth claims. As a result, the religious believer is directed to say "I am the only true religion, the other in fields. Not strange then when at a primary school in the area south of Jakarta happen" brawl "inter-religious students after they learn the religion in the class room. This is really ironic. Yet in recent decades, the nation of Indonesia is promoting inter-religious harmony, respect for the plurality of religious, cultural and ethnic tolerance as well as efforts to build genuine relationships in order to enter an increasingly multi-cultural world.

The effort has resulted in many studies and studies about religion religious pluralism and multi cultureless in Indonesia and put Indonesia as one of the largest Muslim country in the world's most tolerant. In Indonesia there are no less 250 ethnic groups, 250 more local languages, 17,000 islands, and more than five official religions and faiths. However, various obstacles and conflicts continue to color the democratization process in Indonesian. Here the importance of the nation's character-based Islamic education should be directed through a multi-cultural approach. Therefore, the difference is a necessity and Indonesian history is the history of how to manage diversity and multi-cultural as a step to build unity among the various kinds of differences.

This multi-cultural spirit like being challenged continuously from radicals who want to understand the mono cultures society. Society consists of only one culture and civilization. They want the establishment of an Islamic state when the history of Indonesian has emphasized the unitary state based on Pancasila.

But there are still many who seem to feel "allergic" to a multi-cultural country. Yet countries that up hold the spirit of multi-cultural is what actually rests on the real history, not fantasy and utopia. Lawrence A. Blum, in his introduction to the book edited by Larry May, Shari Collins-Chobanian and Kai Wong (2001), Applied Ethics: A Multi-cultural Approach, formulate a multi-cultural philosophy in to three basic frame work.

First, multi-cultural and multiculturalism is in fact an understanding, appreciation and assessment of one's culture. Second, multiculturalism as an effort to respect and curiosity about other people's culture and ethnicity. Third, 
multiculturalism includes efforts to try to see how the culture an express the value for its own members and others.

Of the three basic framework of this philosophy, can be taken understanding that multi-cultural approach can be used for studies on sound national character education. This approach focuses attention on diversity and how to make the existing diversity as an asset of a nation to be managed properly. The goal is how each individual with in a nation can express a value for its own members and others are free.

If the problem is how to put diversity as a national asset that can be managed for the sake of shared values of a nation in order of the plurality of cultures, then multiculturalism is not just at hem that should be studied, understood, or lived in the educational environment. But, more than that, how to practice the values of multi-cultural respect cultural diversity and human behavior in everyday life.

It is this last issue that seems to need to emphasize in the discussion of any idea of a sound national education through multi-cultural approach. If drawn in the context of educational praxis, multi-cultural spirit lately started frequently discussed and seminars, then philosophy at the top should below red to the level of educational units more real. That is, the curriculum must be designed and designed in earnest in the context of preparing students not only to understand what it is multi-cultural education, but how to be multi-cultural, what to do in the face of a plurality of life (well plurality of ethnic, cultural, class, or a plurality language and ethnicity), and how to manage conflict management as a result of differences through multi-cultural approach (Tilaar: 2004; M. Ainul Yaqin: 2007; Ngainun Naim and Achmad Sauqi: 2008; Choirul Mahfud: 2009).

Theoretically, the idea of having to apply the multi-cultural bases in the world of education is not at that follows cultural currents. If we listen to the philosophy of the state and the motto of the Republic of Indonesia, the multi-cultural education actually has a deep-rooted and more than seventy years in this country. This is proof enough capital base to be extracted at the same time as the nation's efforts to achieve increasingly tolerant and cultured towards global cultural currents which now also hit the Indonesian nation.

The founders of the Republic of Indonesia can be an inspiration to us digs their insights and thoughts because they are well aware of the reality of the plurality of Indonesia, so that the foundations of the state, too, show the spirit of embracing diversity without melting into uniformity.

Watch word of our republic so emphatically: "Bhineka Tunggal Ika" (Unity in Diversity)! This is the motto that displays the hope of a great nation to be a multi-cultural nation, a nation that is respected and valued not by the extent of the territory and the multitude of people who inhabit this republic. But, by an attitude of openness and tolerance that is based on honesty, which is shown by the people of Indonesia in the social-political relationships, both at the local level, national, and international levels.

But, in fact daily, the nation of Indonesia As independent nations still often show the gap between the motto and philosophy of the country with the behavior of our life as a nation. In these days of the Indonesian people so easily upset, but once people recognize Indonesia as a nation that is for giving and patient. Currently we so easily provoked to fight just because of the different cast hat have not been able to be managed properly and wisely. So quickly ignite conflict in the country, because of the small problems that we could not managed properly based on the philosophy of Pancasila and the national unity, so that there is a wave of anger that increasingly terrible. Of course we should be optimistic to meet the multi-cultural society which is now waiting in front of us. Because, if not, we worry over time Indonesia is no longer as great and dignified nation, nation that is dying.

So, learn from the failure of the political a authorities in Indonesian managing multi-cultural society, multi-cultural education ethical paradigm it was time to become a source of national life. Multi-cultural education is a form of educational perspective that emphasizes respect for diversity. A theological regarding the assessment of other religions, other cultures and other ethnic, and placing it appropriately in a diverse area of public order in the frame unit.

\section{Research Methods}

In this study researchers use experimental research methods (experimental research) to determine Character Education Insightful Nationality: A Multi-Cultural Approach. Experimental Research is a research that intends to directly investigate the causal relationship of a treatment with an experimental group and control group and the results compared.

\section{Problem Definition: Education and Multiculturalism}

M. Amin Abdullah (2004) believes that multi-cultural education is education out line that seeks to understand the differences that exist in human beings, and how that difference was accepted as natural and not gives rise to discriminatory measures, as the fruit of a pattern of behavior and attitude to life reflects envy, jealousy and prejudice. 
Mean whileTilaar (2004), Indonesian education experts, identifies three layers of discourse relating to multi-cultural education, namely:

a. Issues of culture. In this case there late issues concerning cultural identity of a community or ethnic group.

b. Habits, traditions, pattern of behavior that living in a community.

c. Activities so certain advancement of groups in society which is attached to the identity of the group.

Understanding multi-cultural education comes to an idea or a concept, or an educational reform movement based on efforts to address diversity and differences, which can be taught among students regardless of gender, social class, ethnic, racial, and cultural characteristics.

Multi-cultural education has been born about 30 years ago, that is, after World War with the birth of many countries and the development of democratic principles. The discourse about multiculturalism has been heard since the 1960s and 1970s, which in the West known as the Multi-cultural Based Education. Some education experts are trying to define what it is multi-cultural education, but the definition given did not clarify the problem, let alone provide a way out for the crisis facing the nations a result of the plurality (Tilaar: 2004).

In many countries, the use of the term multi-cultural education is often associated with pluralistic education, inclusive education, which historically birth almost simultaneously with the issue of Islam inclusive and pluralistic Islam in Indonesia, Ngainun Naim and Achmad Sauqi use the term pluralist-multi cultural education. While M. Ainul Yaqin and Zakiyuddin Baidhawy use the term vision of multi cultures a education.

Multi-cultural education was born in response to the development of the diversity of the school population, as demands equal rights for all ethnic groups, religions and languages. In another dimension, a multi-cultural education curriculum development and educational activities for entering various views, history, achievements and concern for those non-Europeans. While broadly multi-cultural education that covers all students regardless their groups such as gender, ethnic, racial, cultural, social and religious strata.

Furthermore, James Banks explained from the other side, that the history of multi-cultural education has five inter related dimensions and in separable:

a. Content integration: integrating various cultures and groups to illustrate basic concepts, generalizations and theories in subjects/disciplines.

b. The Knowledge Construction Process: bring the students to understand the implications of culture in to a subject (discipline).

c. An Equity Pedagogy: Adjusting teaching methods by learning to students in order to facilitate the academic achievement of students who are diverse both in terms of race, culture or social.

d. Prejudice Reduction: Identify the racial characteristics of students and determine their teaching methods.

e. Train groups to participate in sports activities, interact with the entire staff and students of different ethnicities and races in the effort to create a culture of academic (Ngainun Naim and Achmad Sauqi: 2008).

In any educational activity, learners are targets (objects) as well as the subject of education. Therefore, to understand the nature of learners, educators need to include an understanding of the general characteristics of learners. At least in general learners have five characteristics, namely; (1). Learner's role in the state of being powerless, that he was in a state of help lessens s to use the ability, willingness, and so on. (2). Have a desire to grow toward adult hood. (3). Learners have different back grounds. (4). Learners conduct the exploration of the natural surroundings with a potential base owned individually (Ngainun Naim and Achmad Sauqi: 2008).

Regarding Tilaar(2004) the focus of multi-cultural education, revealed that in the multi-cultural education program, the focus is no longer directed solely to the racial groups, religious and cultural domain or dominant. Focus like this ever beepers sure on inter cultural education that emphasizes an increased understanding and tolerance of individuals who come from minority groups against the dominant main stream culture, which in turn led to people from minority groups are integrated into main stream society. Multi-cultural education is actually an attitude of "caring" and want to understand the cultural differences and the recognition of people from minority groups.

\section{Character Education Insight Full Nationality: Multi Cultural Approach}

Character education actually is not merely a matter of debate discourse education experts in various mass media and scientific journals, but has now been implemented in various schools and madrassas. It can be regarded as a positive development, as it is expected that many people-especially the initiators of character education. However, given the character education has not had a strong foot hold in curriculum development in schools, it raises concerns: lest implementation of character education that starts in schools is currently developing sporadic, vague concepts and objectives to be achieved, Pattern formation of character was impressed impose themselves by entering a character- 
based education as part of moral education(Heri Goenawan: 2001).

In the version of the Ministry of National Education of Indonesia, the goal of character education is not much different with the goal of moral education; namely realizing public morals, moral, ethical, cultured, and civilized. Meaning the characteristic refers to the meaning of' character', which is often interpreted as a mental attitude that affects all human thought and behavior, manners, and character. That is, the values of character that relates to moral force which con notes 'positive'. Thus, 'the character' is people have moral qualities (specific) positive. Education builds character, implicitly implies building traitor behavior pattern that is based on or related to the positive moral dimension.

Thus, character education is not a new subject, but how each subject existing ones capable imbued by the values of the characters. The process of character formation of students in upper secondary school level can be held by Islamic religious education, civic education and Indonesian. That is, the base character values that are applied are not separate with other subjects. Characters in to orbits expected to illuminate and animate all subjects capable of existing.

Description of the above character education is not new to Indonesia. At least, since Ki Hajar Dewantara, it appears the problem of character, especially when Ki Hajar Dewantara sees the man on the psychological side of life, which has a trilogy faculty, namely creativity, initiative and work. The formation of human character in the third educational institution requires a balance that power. Education that only emphasizes the sheer intellectual aspects, would deprive students of their communities, and it turns education until now only emphasizes on the development of creativity and lack of attention to the development of feeling and intention (Zaim Al-Mubarak: 2008).

In the current context, the development of creativity and initiative is conducted through character education is now becoming one of the strong concern of the government. Character education should be developed within the framework of the national education system as whole normative references, formulated in a systematic framework.

It was never stated by Sunaryo Kartadinata, need to be exemplary character formation, real behavior in the setting of an authentic life and cannot be built in an instant. Therefore, the formation of character must be a moral movement that is holistic, involving various stakeholders and channels, and takes place in a setting of natural life. Even described in more detail, that there is a core value in the character derived from the culture. We cannot build character in spite of our own culture. Education over the generations should be done early, and the best of provisions is given for future generations is character education (Thomas Lickona: 2012).

Nationality insight character education can be a way out like business-multi culturist realizes pluralist society in Indonesia. For insight into the Indonesian nationality requirement with multi-cultural values. Of philosophy and that ideology and the motto contain any multi-cultural state. The nationality insight educational purposes in line with the objective of multi-cultural philosophies as an alternative through the implementation of educational strategies and concepts based on the utilization of the diversity that exists in society, particularly that of the students such as ethnic diversity, culture, language, religion, social status, gender, ability, age and race. And most importantly, multi-cultural education is not only aimed so that students easily understand the lessons learned in school, but also to increase their awareness in order to always behave humanist, pluralist and democratic (Ainul Yaqin: 2004).

In multi-cultural education, contained the principle of social justice, democracy, and human rights. Multi-cultural education emphasizes the principle of equality of all before the law. Multi-cultural education does not discriminate against students because of different religion, race, ethnicity, language and class. Multi-cultural education principled antidiscrimination, anti-subordination, non-violence. According Hamim llyas (2005), one of the principles of multi-cultural education in generals based on the pedagogical principle of equality (equity pedagogy) which originates in the equality of human dignity.

The principles of multi-cultural education when viewed from the perspective of Islam, it is not contradictory. Islam emphasizes coexistence in diversity by means of mutual appreciation, respect and tolerance. The Islamic view is associated with the freedom of religious belief is based on the Qur'an Surat al-Baqarah: 256: "There is no compulsion to (embrace) the religion(Islamic); actually has obviously the right way with a false path".

In addition, there's more verse in the Quran which emphasizes mutual respect for cultural differences. Regarding recognition of the Quran, contained in the letter of al-Maidah verse 69: "Verily, those who believe, Jews, Sabena's, and the Christians, who (among them) who truly believe in Allah and the Last Day, and work righteousness, it is no concern to them and not (also) they grieve". Then can be read also in the letter of al-Maidah verse 82 when God said: "In deed we found the most violent enmity against those who believe are the Jews and the idolaters. And ye find the closest friendships with those who believe are those who say: "We have the Nazarenes". That is because amongst them are priests and monks, (also) because they are not arrogant".

Meanwhile, in a letter Hud verses 118-119, Allah also emphasize the significance difference as sunnatullah. Allah says: "If thy Lord had willed, He made human beings are one, but they always disagree, except those who were given the grace by your Lord. And, for that He created them". "Because they are different then God created them", said Muhammad 
Emirate. And this is pointed out by the hadith narrated by Bukhari and Muslim, which means: "The prophets are brothers, from different mothers. Their religion is one and their mother is different."

There are many role models in the Hadith of the Prophet Muhammad to Muslims who are able to appreciate diversity. Husna Khotimatul authored a book titled 40 Hadith Sahih, Tolerance Building Code. In this book there are forty Prophet Muhammad related to multi-cultural education, respecting the rights of other religions, respecting other religions, respecting the culture, race, ethnicity, class.

Prophet exemplifies how to behave with non-Muslims in the war, and obviously there was no hostile command, in steademph a sized to respect. Islam respects the rights of non-Muslims. It is as found in Sahihal-Bukhari hadith number 2824: "It was narrated from Ibn Musa Ismail, from Ibn Amir Maimon, from Amir, he inte state about in fidel dhimmis:" It should be fulfilled agreements deal with them, not fight them from behind, and not too burdensome beyond their capabilities".

Islam teaches to not persecute the enemy. In fact, Islam teaches us to respect the rights of the infidels in the war, and should not be brutally slaughtered. In another hadith, the Prophet are to respect religious differences because of religious differences is sunnatullah. Prophet Muhammad had also said: "From Abu Ya' la Shaddad bin Ausshollallahuradhiallahuanhu of the Prophet 'alaihiwasallam said:" Verily Allah obliges doing good (ihsan) over everything. If you kil l(inwar) then do good in how to kill, and if you slaughter, then do good in the way of slaughter, let one of you sharpen is machete and pleasant victim"

Prophet sallallaahu 'alaihiwasallam also said: "Most major faith is patience and tolerance." Further, from Radliyallahu Aisha' an ha, she reported: "The Prophet sallallaahu 'alaihiwasallam called me while children play Habasyah spears in the mosque at the feast, he offered: "O Humairo! Do you like to look at their game?" I replied: Yes !. So he told me to stand behind him, then he bowed his shoulders so I could see them, I will put down my chin over his shoulder and leaned my face on his cheek, then I will look on both his shoulders, while he said: "O children of Play Arfadah! "Then the hose after wards he asked: "O Aisha! You've satisfied?" I said: "Not yet" So I see my position beside him, until I will be satisfied. He said: "Enough?" I replied: "Yes". He said: "Then go!". Aisha said: "Then Umar appeared, the people and the children had left them scattered (Habasyah), the Prophet sallallaahu 'alaihiwasallam said, which means:" I saw the man and jinn syaithan run of Umar ". Aisha says: Prophet sallallaahu 'alaihiwasallam when it said: "To the Jews know that in our religion there is freedom, I was sent to Al-Hanifiyah (right religion) As-Samhah (easy)". The Prophet said, which means: "The angel gathered spirit of a man of the people before you. They asked: 'Do you ever do good?' He replied: 'I used to tell the clerk to give tough people who have difficulty (in repaying the loan, -pent) and forgive people easily Allaah says:" Please forgive him"

Based on the arguments ofthe Qoran and the Hadith above, it can be said that Islam really appreciate pluralism and diversity, respect for cultural differences in people's lives. We can see, in the frame work of the unity of man, God created diverse peoples, diverse island, a variety of language, race, color and diverse cultures. Within the framework of the unity of a nation, God created the diverse tribes. Within the frame work of the unity of a language, God also created a wide variety of dialects and sub-dialects are huge numbers.

Can Islam develop a multi-cultural approach, while at the same timeless develop an appreciation of the culture, including the local perspective? It was difficult to answer in the affirmative, especially if the idea of a multi-cultural still considered something foreign in Islamic education and are always suspect because they do not come from Indonesia subculture. Therefore, the task of educators today is to introduce the spirit of sound national education through multicultural approach to learners from early childhood.

Noble ideals in a multi-cultural national awareness in Indonesia did not conflict with the norms of the religion (Islam). However, the theoretical basis remains problematic for some people. Multi-cultural values are considered extrareligious rejected by Muslim theologians, making it difficult to explore the themes of Islamic education from an early age, except in college like IAIN and UIN.

\section{Conclusion}

The above exposition not challenge so severe if the political elite and the government together with the community to have a commitment to build a pluralistic Indonesia once civilized, harmonious and peaceful at the same fair. This is the common task ahead: how to recognize and minimize misunderstandings and misperceptions regarding the multi-cultural approach that is always suspected of being foreign in Islamic education approach. If this task successfully, Indonesia can introduce multi-cultural approach to students has been since the early childhood education so that it will open an embedded character, humanist, mutual respect for differences and diversity that greet each other.

The challenge of the world of Islamic in Indonesia is to realize the spirit and ideals of pluralistic and diverse 
nationalities in real life. Various theories and studies regarding this issue has been quite a lot to be utilized in the realization of the national vision of multi-cultural education. Because the fact history shows that Indonesian was built and founded on the fact of plurality and diversity of ethnicity, language, culture, ethnicity and religion and cult.

\section{References}

Abdurrahman Wahid (ed), The illusion of an Islamic State: Expansion of Transnational Islamic Movement in Indonesia, The Wahid Institute bekerjasama Maarif Institute, Jakarta, 2009

Choirul Mahfud, Multicultural Education, Pustaka Pelajar, Yogyakarta, Cet. ke-3, 2009

Hamim Ilyas, "Multicultural Education In Discourse Tafsir Al-Quran", Papers Multicultural Education Seminar organized by the Center for Cultural Studies and Social Change Muhammadiyah University of Surakarta (UMS) in Surakarta on January 8, 2005

H.A.R. Tilaar, Multiculturalism (Challenges in the Global Future Transformation of National Education), Grasindo, Jakarta, 2004

Heri Gunawan, Character Education: Concepts and Implementation, Alfabeta, Bandung, 2012

Larry May, Shari Collins-Chobanian, dan Kai Wong, I and II Applied Ethics: A Multicultural Approach, translation Sinta Carolina, Dadang Rusbiantoro, Tiara Wacana, Yogyakarta, 2001

Muhammad WahyuniNafis, "Inclusive Islamic building in Life", Kompas, 03 Agustus 2001

M. Ainul Yaqin, Multicultural education: Cross-Cultural Understanding for Democracy and Justice, Pilar Media, Yogyakarta, 2007

M. Amin Abdullah, "Multicultural Awareness: A Movement 'Interest Minimalization' In Relieve Social Conflict", Introduction to the book M. Ainul Yaqin, Multicultural Education: Cross-Cultural Understanding for Democracy and Justice, Pilar Media, Yogyakarta, 2007

Ngainun Naim dan Achmad Sauqi, Multicultural education: Concepts and Applications, Ar-Ruzzmedia, Yogyakarta, 2008

Thomas Lickona, Educating for Character Forming, Trans. Jama Abdu Wanangodari Educating for Character, Bumi Aksara, Jakarta, 2012

Zaim Al-Mubarak, Summing up the grounding Values Scattered, Connecting the Disconnected and Unite are parted, Alfabeta, Bandung, 2008. 